Article

\title{
Exploring the Phytochemicals of Acacia melanoxylon R. Br.
}

\author{
Diana Alves ${ }^{1}$, Sidónio Duarte ${ }^{1}$, Pedro Arsénio ${ }^{2}{ }^{\circledR}$, Joana Gonçalves ${ }^{3}$, Cecília M. P. Rodrigues ${ }^{3}{ }^{\circledR}$, \\ Ana Lourenço ${ }^{1, *(\mathbb{D})}$ and Patrícia Máximo ${ }^{1, *(1)}$ \\ 1 LAQV-REQUIMTE, Department of Chemistry, NOVA School of Science and Technology, NOVA University, \\ 2829-516 Caparica, Portugal; dfl.alves@campus.fct.unl.pt (D.A.); sidonioduarte88@gmail.com (S.D.) \\ 2 Linking Landscape, Environment, Agriculture and Food (LEAF)—Research Center, Associated Laboratory \\ TERRA, Instituto Superior de Agronomia, Universidade de Lisboa, Tapada da Ajuda, \\ 1349-017 Lisbon, Portugal; arseniop@isa.ulisboa.pt \\ 3 Faculty of Pharmacy, Research Institute for Medicines (iMed.ULisboa), Universidade de Lisboa, Av. Prof. \\ Gama Pinto, 1649-003 Lisbon, Portugal; joanalmg@hotmail.com (J.G.); cmprodrigues@ff.ulisboa.pt (C.M.P.R.) \\ * Correspondence: ana.lourenco@fct.unl.pt (A.L.); psm@fct.unl.pt (P.M.)
}

Citation: Alves, D.; Duarte, S.; Arsénio, P.; Gonçalves, J.; Rodrigues, C.M.P.; Lourenço, A.; Máximo, P. Exploring the Phytochemicals of Acacia melanoxylon R. Br. Plants 2021, 10, 2698. https://doi.org/10.3390/ plants10122698

Academic Editors: Barbara Sladonja and Danijela Poljuha

Received: 12 November 2021

Accepted: 2 December 2021

Published: 8 December 2021

Publisher's Note: MDPI stays neutral with regard to jurisdictional claims in published maps and institutional affiliations.

Copyright: (C) 2021 by the authors. Licensee MDPI, Basel, Switzerland. This article is an open access article distributed under the terms and conditions of the Creative Commons Attribution (CC BY) license (https:// creativecommons.org/licenses/by/ $4.0 /)$.

\begin{abstract}
Invasive species are currently a world menace to the environment, although the study of their chemistry may provide a means for their future beneficial use. From a study of Portuguese Acacia melanoxylon R. Br. five known compounds were isolated: lupeol, 3ß-Z-coumaroyl lupeol, $3 \beta$-E-coumaroyl lupeol (dioslupecin A), kolavic acid 15-methyl ester and vomifoliol (blumenol A). Their structures were elucidated by 1D and 2D NMR spectroscopy and mass spectrometry, and as a result some corrections are made to their previous ${ }^{13} \mathrm{C} N \mathrm{NR}$ assignments. Cytotoxicity of $3 \beta-E-$ coumaroyl lupeol (dioslupecin A) and kolavic acid 15-methyl ester was evaluated against HCT116 human colorectal cancer cells although biological activity was not evident.
\end{abstract}

Keywords: invasive species; Acacia melanoxylon; terpenoids; HCT116 human colorectal cancer cells; cytotoxicity

\section{Introduction}

Plant invasive species are one of the great threats to biodiversity since they establish and supersede native species, leading occasionally to the extinction of the latter, by disrupting the biotic and abiotic balance of the invaded ecosystem. Apart from this ecological impact, they also have a socio-economic impact by influencing human health, infrastructures and local economies [1,2]. These species have long been a concern in the Portuguese territory [3-5] and elsewhere, which resulted in the publication of legal regulations to prevent and manage the introduction and spread of invasive alien plants, both at the national [6] and European level [7,8]. The management of this problem in Europe costs millions of euros [9] and, since eradication is rarely achieved, actions end up frequently with periodic growth control and containment of these species [10]. The use of invasive species as a source of chemicals or pharmaceuticals allows a rational use of resources that can mitigate the cost of their control, turning a useless and abundant natural good into an added value resource [11]. Most likely, the prevalence of invasive species over endemic ones relies on the bioactivity of the metabolites they produce as invaders, that are surely responsible for their ease of expansion and dominance of the new habitat [11,12].

Bearing this in mind, we began our studies on the chemistry of invasive Acacia species. Acacia species, mainly from Australia, settled in the Mediterranean area and conquered significant lands. In Portugal they are distributed throughout the country, preferentially on acid substrates. Originally, they were introduced as a source for wood, as an erosion preventer, for reforestation purposes and for ornamental reasons and the perfume industry, among others $[13,14]$. Abiotic and biotic factors favored their establishment and with time some of their uses deteriorated and economic value lowered, leading to an increase in their abundance and to an invasion condition [14-16]. The management and control of 
Acacia invasions includes various steps, from risk assessment to containment, eradication and ecosystem restoration actions [13,15,17]. Some of the containment and control actions include mechanical removal (ring-barking, hand-pulling or cutting) followed by chemical control (with glyphosate), or biological control [18].

A. melanoxylon R. Br. (Australian blackwood) is a $15 \mathrm{~m}$ tree with evergreen leaves and pale-yellow flowers arranged in a globular head of 10-12 mm diameter. Flowering occurs in Portugal from February to June, and its fruits are brownish red pods. The seeds, encircled by an orange funicle, remain viable in the ground for more than 50 years, are dispersed by birds, wind, water, or rodents, and germinate after a space opening and/or fire occurrence. This species also propagates vegetatively, forming vigorous sprouts from the stump and roots [19].

Previous studies on the chemistry of $A$. melanoxylon include the isolation of hyperoside (quercetin-3-D-galactoside) from the flowers [20], dihydroflavonoids [21], hydroxyflavans [22], leucoanthocyanidins [23-25], a pyrogallol A-ring proanthocyanidin dimer [26], [4-O-4]-linked biflavanoids [27] from the heartwood, and acamelin (a furanoquinone) and a benzoquinone from undisclosed parts [28]. Studies from Portuguese invasive species include the identification of $\Delta^{7}$ phytosterols, phytosteryl glucosides and long-chain $n$-alkyl caffeates by GC-EIMS from the dichloromethane extracts of wood and bark [29,30], as well as the antimicrobial activity of aqueous, ethanolic and methanolic leaf extracts, that showed no interesting results [31]. Other references to bioactivity of extracts of this species can be found in the recent review by Correia et al. on the biomass valorization of Acacia species [32].

Following our interest in the chemistry of invasive species, in this study we report on the isolation of five compounds: lupeol 1 [33], 3 $\beta$-Z-coumaroyl lupeol 2 [34,35], $3 \beta$ E-coumaroyl lupeol (dioslupecin A) 3 [36,37], kolavic acid 15-methyl ester 4 [38-40] and vomifoliol (blumenol A) 5 [41-43] from a Portuguese invasive A. melanoxylon and demonstrate the utility of investigating its phytoconstituents, and as corollary of invasive species in general.

For compound 3, previous biological activity studies regard the cytotoxicity studies on KB, COLO-205, HEPA-3B, and HELA cell lines and showed no activity [37].

For compound 4, biological activity studies have been performed, namely inhibitory (Trypanosoma brucei) [38], and antimicrobial (Escherichia coli, Proteus sp., Streptococcus aureus and Candida albicans) [39] activities, as well as cytotoxicity (AGP01, HCT116, MCF07, NIHOVCAR, SKAMELL4 and SF295 cell lines) and anti-inflammatory activities [40]. Although antimicrobial activities and cytotoxicity were not observed, compound 4 showed high lipoxygenase inhibition activity when compared to standard quercertin and inhibited the production of IL-6 [40]. It also exhibited an inhibitory activity on the growth of Trypanosoma brucei with respect to the clinically used antitrypanosomal agents suramin and melarsoprol and showed a strong and selective inhibitory activity on the GAPDH enzyme of T. brucei [38].

For compound 5, previous anticancer studies showed no significant activity (HIF-1 and NF- $\mathrm{KB}$ activities in reporter assays, and in cytotoxicity against A549, MDA-MB-231, MCF-7, KB, KB-VIN, HT29, A498, PC3 and PACA2 cell lines) [43-45]. Antimicrobial (Micrococcus tetragenus, Escherichia coli, Staphylococcus albus, Bacillus cereus, Staphylococcus aureus, Micrococcus luteus, Bacillus subtilis, Pseudomonas aeruginosa, methicillin-resistant Staphylococcus aureus, Vibrio parahemolyticus and Candida albicans), DPPH free radical scavenging, acetylcholinesterase inhibitory and brine shrimp larvicidal activities also showed no results $[42,46]$.

\section{Results and Discussion}

\subsection{Compound Identification}

From the dichloromethane extract $(17.63 \mathrm{~g})$ of $A$. melanoxylon $\mathrm{R}$. Br. (1250 g) collected at Peninha, Sintra, Portugal, lupeol 1 [33] (purified, $<0.1 \mathrm{mg}$ ), 3 $\beta$-Z-coumaroyl lupeol 2 [34,35] (purified, $15.6 \mathrm{mg}$ ), 3ß-E-coumaroyl lupeol (dioslupecin A) 3 [36,37] (purified, $39.0 \mathrm{mg}$ ), 
and kolavic acid 15-methyl ester 4 [38-40] (purified $111.1 \mathrm{mg}$ ) were isolated (Figure 1). The study of the alkaloid content of this species led instead to the isolation of vomifoliol (blumenol A) 5 [41-43] (unpurified, $5.4 \mathrm{mg}$ ). Alkaloids were detected by TLC but their isolation was not achieved due to the low content in this species (this may be related to the time of harvest, since the accumulation of alkaloids is known to be seasonal, or due to other biotic or abiotic factors).

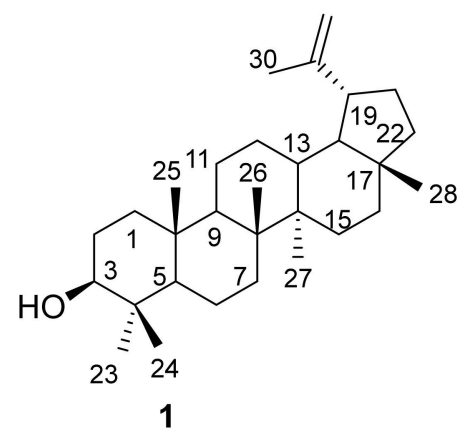<smiles>C=C(C)[C@H]1CC[C@]2(C)CC[C@]3(C)C(CCC4[C@@]5(C)CC[C@H](OC(=O)/C=C/c6ccc(O)cc6)[C@H](C)C5CC[C@]43C)C12</smiles>
3

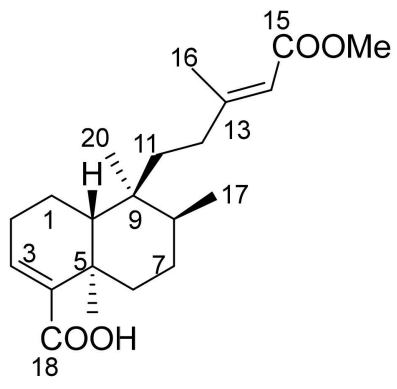
4<smiles>C=C(C)[C@H]1CC[C@]2(C)CC[C@]3(C)C(CCC4[C@@]5(C)CC[C@H](OC(=O)/C=C\c6ccc(O)cc6)C(C)(C)C5CC[C@]43C)C12</smiles>

2<smiles></smiles>

5

Figure 1. Lupeol 1,3ß-Z-coumaroyl lupeol 2, 3ß-E-coumaroyl lupeol (dioslupecin A) 3, kolavic acid 15-methyl ester 4 and vomifoliol (blumenol A) 5 isolated from A. melanoxylon.

The use of 1D and 2D NMR allowed the structure determination of all five compounds, further confirmed by mass spectrometry and comparison with literature data (Figure 1).

Compound 1 was identified by its characteristic $\mathrm{H}-3(\delta 3.19 \mathrm{ppm}, d d, J=5.0 \mathrm{~Hz}$, $J=11.2 \mathrm{~Hz}$ ), aliphatic methyl groups ( $\delta 0.76 \mathrm{ppm}, 0.79 \mathrm{ppm}, 0.83 \mathrm{ppm}, 0.94 \mathrm{ppm}, 0.97 \mathrm{ppm}$ and $1.03 \mathrm{ppm}), \mathrm{CH}_{2}-29$ ( $\delta 4.56 \mathrm{ppm}$, sl and $\left.\delta 4.56 \mathrm{ppm}, \mathrm{sl}\right)$ and $\mathrm{Me}-30(\delta 1.68 \mathrm{ppm})$ resonances (Figure S1), all in agreement with literature values [33]. Comparison of the NMR spectra of 2 (Figures S2-S8) and 3 (Figures S9-S14) with that of $\mathbf{1}$ (Figure S1) allowed the recognition of a lupeol base skeleton substituted at C-3 with a coumaroyl unit-the structures of $3 \beta$ Z-coumaroyl lupeol 2 [34,35] and 3 $\beta$-E-coumaroyl lupeol (dioslupecin A) 3 [36,37] were proposed, based on the $J$ value couplings of the substituent's double bond $(12.7 \mathrm{~Hz}$ and 
$15.9 \mathrm{~Hz}$, respectively). Further confirmation came from comparison of the ${ }^{1} \mathrm{H}$ and ${ }^{13} \mathrm{C}$ resonance values with those of the literature [34-37].

For compound 3 corrections are made for the literature $[36,37]$ resonances of the aliphatic methyl groups, based on HMBC and NOESY correlations (Table 1): HMBC between $\delta 0.89$ and $\delta 0.92$ with $\delta 81.2$ (C-3) clearly indicates the presence of Me-23 and Me-24, distinguished by NOESY with H-3 (for $\delta 0.89$ ); HMBC of $\delta 0.88$ with $\delta 50.3$ (C-9) and $\delta 37.1$ (C-10) assigns Me-25; HMBC of $\delta 1.03$ with $\delta 34.2$ (C-7), $\delta 40.8$ (C-8), $\delta 42.8$ (C-14) and $\delta 50.3$ (C-9) assigns Me-26; HMBC of $\delta 0.95$ with $\delta 27.4$ (C-15) and $\delta 42.8$ (C-14) assigns Me-27; finally, HMBC of $\delta$ 0.79 with $\delta 35.5$ (C-16), $\delta 43.0$ (C-17) and $\delta 48.2$ (C-18) assigns Me-28.

Table 1. ${ }^{1} \mathrm{H}$ and ${ }^{13} \mathrm{C}$ resonances of the aliphatic methyl groups of $3 \beta$-E-coumaroyl lupeol $3\left(\mathrm{CDCl}_{3}\right.$, 400 and $100 \mathrm{MHz})$.

\begin{tabular}{ccc}
\hline & ${ }^{\mathbf{1}} \mathbf{H}(\boldsymbol{\delta} \mathbf{~ p p m})$ & ${ }^{\mathbf{1 3}} \mathbf{C}(\boldsymbol{\delta} \mathbf{p p m}){ }^{*}$ \\
\hline Me-23 & 0.89 & 28.0 \\
Me-24 & 0.92 & 16.6 \\
Me-25 & 0.88 & 16.2 \\
Me-26 & 1.03 & 15.9 \\
Me-27 & 0.95 & 14.5 \\
Me-28 & 0.79 & 18.0 \\
\hline
\end{tabular}

* assigned by HSQC.

On purification and analysis, isomerization of the double bond was observed as described previously for coumaroyl esters [47]: the final ${ }^{1} \mathrm{H}$ NMR spectrum of the sample of 2 is composed of a 2.0:1.0 mixture of $E$ and $Z$ isomers (Figure S15), also present in the chromatogram of the GC-FID analysis (1.6:1.0, different ratios accountable by different isomerization times, Figure S16). Even the $E$ isomer, compound 3, obtained in pure form, seems to equilibrate in $\mathrm{CDCl}_{3}$ to a 4.4:1.0 mixture of $E$ and $Z$ forms (Figure S17).

For compound 4, a detailed analysis of the NMR data led to the proposed structure, confirmed by the $\left[\mathrm{M}-\mathrm{H}_{2} \mathrm{O}+\mathrm{H}\right]^{+}$and $[\mathrm{M}-\mathrm{H}]^{-}$ions present at $\mathrm{m} / \mathrm{z} 331.3 \mathrm{u}$ and $\mathrm{m} / \mathrm{z} 347.2$ $\mathrm{u}$ in the positive and negative ESI-MS spectra, respectively (Figures S18-S25). Analysis of the spectra and comparison of the NMR resonances with those of the literature [38-40] allowed us to make some corrections to previously assigned ${ }^{13} \mathrm{C}$ NMR values that should be interchanged: (a) C-2 and C-7: interchanged based on HMBC with H-3 and Me-17, respectively; (b) C-6 and C-11: interchanged based on COSY of H-12 with $\mathrm{H}-11$ (C-11, assigned by HSQC); (c) Me-19 and Me-20: interchanged based on HMBC with C-11; (d) C-5 and C-9: interchanged based on HMBC correlations of Me-19 and Me-20, respectively; and (e) C-15 and C-18: interchanged based on HMBC of the OMe group (confirmed by $\mathrm{HMBC}$ of $\mathrm{H}-14)$. Table 2 lists the full ${ }^{13} \mathrm{C}$ NMR assignment and the ${ }^{1} \mathrm{H}$ NMR outstanding resonances (full ${ }^{1} \mathrm{H}$ NMR assignment can be found in the literature [38-40]).

Table 2. ${ }^{13} \mathrm{C}$ assignment and the ${ }^{1} \mathrm{H}$ outstanding resonances of kolavic acid 15 -methyl ester $4\left(\mathrm{CDCl}_{3}\right.$, 125 and $500 \mathrm{MHz}$ ). $s$ singlet, $d$ duplet, $t$ triplet.

\begin{tabular}{cccccc}
\hline & ${ }^{\mathbf{1}} \mathbf{H}$ & ${ }^{{ }^{13} \mathbf{C}}$ & & ${ }^{\mathbf{1}} \mathbf{H}$ & ${ }^{\mathbf{1 3}} \mathbf{C}$ \\
\hline 1 & & 16.8 & 11 & & 36.2 \\
2 & 24.4 & 12 & & 34.4 \\
3 & $6.80 t 3.8$ & 142.2 & 13 & & 161.5 \\
4 & & 137.5 & 14 & $5.68 d 1.0$ & 114.9 \\
5 & 36.3 & 15 & & 167.3 \\
6 & 36.8 & 16 & $2.18 d 1.2$ & 19.2 \\
7 & 28.6 & 17 & $0.77 d 6.9$ & 15.9 \\
8 & 37.8 & 18 & & 172.7 \\
9 & 40.3 & 19 & $1.24 s$ & 33.4 \\
10 & 45.4 & 20 & $0.78 s$ & 18.0 \\
& & & COOMe & $3.69 s$ & 50.8 \\
\hline
\end{tabular}


Finally, for compound 5, the proposed structure based on NMR analysis was confirmed by the $\left[\mathrm{M}-\mathrm{H}_{2} \mathrm{O}+\mathrm{H}\right]^{+},[\mathrm{M}+\mathrm{H}]^{+},[\mathrm{M}+\mathrm{Na}]^{+}$and $[\mathrm{M}-\mathrm{H}]^{-}$ions present at $m / z 207.1 \mathrm{u}$, $\mathrm{m} / \mathrm{z} 225.1 \mathrm{u}, \mathrm{m} / \mathrm{z} 247.1 \mathrm{u}$, and $\mathrm{m} / \mathrm{z} 223.0 \mathrm{u}$ in the positive and negative ESI-MS spectra, respectively (Figures S26-S32). Comparison of the ${ }^{1} \mathrm{H}$ and ${ }^{13} \mathrm{C}$ NMR resonances with those of the literature [41-43] confirm the structure, and allows us to correct the ${ }^{13} \mathrm{C} N M R$ $\delta$ values of the $\Delta^{7}$ double bond that must be interchanged: C-7 $\delta 129.0 \mathrm{ppm}$ and C-8 $\delta$ 135.7 ppm (ascertained by HSQC).

\subsection{Cytotoxicity Evaluation}

Cytotoxicity studies were performed for kolavic acid 15-methyl ester 4 and a sample of $3 \beta-E$-coumaroyl lupeol (dioslupecin A) 3. The fact that compounds 2 and 3 equilibrate when in solution prevented us from testing both compounds separately. Since lupeol $\mathbf{1}$ and vomifoliol (blumenol A) 5 were isolated in small amounts their biological testing was also not performed.

To determine cellular toxicity, preliminary assays were performed with compounds 3 and 4 incubated in HCT116 cells for $72 \mathrm{~h}$. Compound 3 showed to decrease cell viability to $64 \%$ only at the highest concentration tested $(243 \mu \mathrm{M})$. However, at the same concentration, compound 4 decreased cell viability to $3 \%$.

Therefore, only the IC50 of compound 4 was determined by the MTS metabolism assay, in order to evaluate its potential cytotoxic activity. In fact, compound 4 showed to have a relatively low cytotoxicity against the HCT116 colon cancer cell line, with an IC50 value of $176.3 \mu \mathrm{M}(95 \% \mathrm{CI}=163.8$ to $189.8 \mu \mathrm{M}$, Figure 2). This might suggest its use as an anti-inflammatory agent [40]. Nonetheless, additional studies using other cell lines are required to discard completely the cytotoxic effect of this compound. 5-Fluorouracil (5-FU), a cytotoxic agent in colon cancer treatment, was used as a positive control (IC50 value of $2.763 \mu \mathrm{M} ; 95 \% \mathrm{CI}=2.539$ to $3.007 \mu \mathrm{M}$, Figure 3).

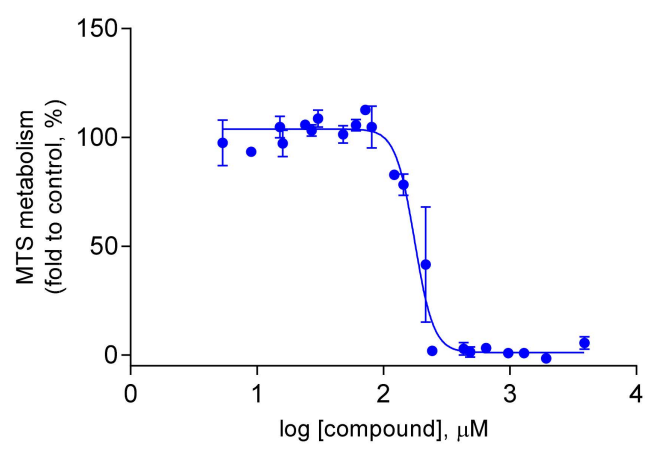

Figure 2. Dose-response curve in HCT116 cells upon incubation with compound 4 for $72 \mathrm{~h}$. These results are representative of at least three independent experiments.

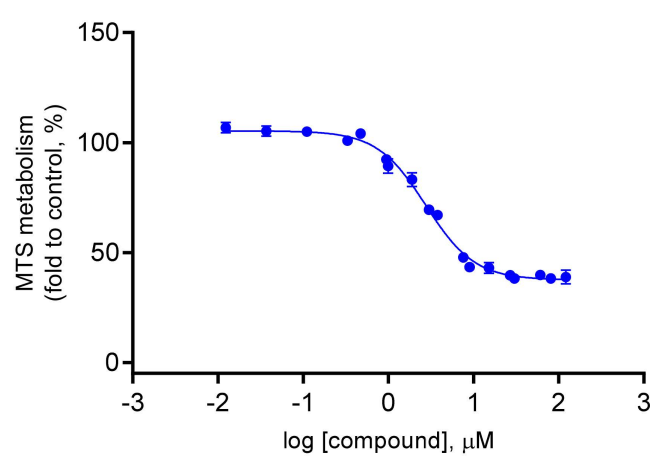

Figure 3. Dose-response curve in HCT116 cells upon incubation with 5-FU for $72 \mathrm{~h}$. These results are representative of at least three independent experiments. 


\section{Materials and Methods}

\subsection{General Experimental Procedures}

Silica gel 60 for chromatography (Merck 7734 or Merck 109385) was used for column chromatography (gravity and flash, respectively) and TLC was performed on Silica gel 60 Merck $5744(0.5 \mathrm{~mm})$ or 5554 TLC plates employing $254 \mathrm{~nm}$ and/or $366 \mathrm{~nm}$ UV-lamp for visualization. Molybdophosphoric acid or Munier Dragendorff reagent were used for additional spot development [48]. NMR spectra were recorded on a $400 \mathrm{MHz}\left(100 \mathrm{MHz}\right.$ for $\left.{ }^{13} \mathrm{C}\right)$ Brucker Avance III 400 or $500 \mathrm{MHz}\left(125 \mathrm{MHz}\right.$ for $\left.{ }^{13} \mathrm{C}\right)$ Bruker AVANCE Neo 500 spectrometer (Fällanden, Switzerland) at $25^{\circ} \mathrm{C}$ using standard pulse programs. Residual solvent signals were used for calibration $\left({ }^{1} \mathrm{H}: \delta\left(\mathrm{CHCl}_{3}\right)=7.26 \mathrm{ppm},{ }^{13} \mathrm{C}: \delta\left(\mathrm{CDCl}_{3}\right)=77.00 \mathrm{ppm}\right)$. GC-FID was performed on GC Agilent 6890 operated at the following conditions: carrier gas Helium, split ratio 1:30; Column: ZB1HTinferno, L: $15 \mathrm{~m}, \varphi: 0.25 \mathrm{~mm}$, df: $0.10 \mu \mathrm{m}$, injector temperature $280^{\circ} \mathrm{C}$; detector temperature $280^{\circ} \mathrm{C}$; temperature program $100^{\circ} \mathrm{C}$, hold for $0 \mathrm{~min}$, increase $10^{\circ} \mathrm{C} / \mathrm{min}$ to $320^{\circ} \mathrm{C}$, hold for $20 \mathrm{~min}$.

ESI-MS spectra were performed on a Thermo orbitrap Qexactive focus apparatus with direct inlet by a Thermo vanquish apparatus.

\subsection{Plant Collection and Preparation}

Branches and leaves of A. melanoxylon R. Br. were collected at Peninha, Sintra, Portugal $\left(38^{\circ} 46^{\prime} 10^{\prime \prime} \mathrm{N} 9^{\circ} 27^{\prime} 33^{\prime \prime} \mathrm{W}\right)$, on 15 December 2019 and a voucher specimen (LISI032915, Patrícia Máximo and Ana Lourenço, s.n., collected on 1 March 2020) was deposited at Herbário João de Carvalho e Vasconcellos (LISI), School of Agriculture (ISA), University of Lisbon. After air drying at room temperature in the dark, and milling, $1850 \mathrm{~g}$ were obtained.

\subsection{Extraction and Isolation}

\subsubsection{Dichloromethane Extract}

An amount of $1250 \mathrm{~g}$ of $A$. melanoxylon $\mathrm{R}$. Br. was defatted with $n$-hexane and extracted with $2.5 \mathrm{~L}$ of dichloromethane (DCM), at room temperature for $5 \mathrm{~h} 30 \mathrm{~min}$. After this time the plant material was separated and re-extracted with another $2.5 \mathrm{~L}$ of dichloromethane, at room temperature, for $18 \mathrm{~h}$. The gathered filtrates were evaporated to yield $17.63 \mathrm{~g}$ of extract.

The extract was chromatographed on gravity column (diameter $15.0 \mathrm{~cm}$, height $25 \mathrm{~cm}$ ) with mixtures of $n$-hexane/ethyl acetate, ethyl acetate, two mixtures of ethyl acetate/methanol and methanol to yield 7 fractions (DCM1 (8/2), DCM2 (7/3), DCM3 (6/4), DCM4 (1/1), DCM5 (EtOAc), DCM6 (10\% and 20\% of MeOH), DCM7 (MeOH)).

The fraction DCM1 $(4.13 \mathrm{~g})$ was purified by flash chromatography with a mixture of $n$-hexane/ethyl acetate $9 / 1$ to yield six fractions, two of them further purified: DCM1E and DCM1F. The fraction DCM1E $(638.0 \mathrm{mg})$ was purified by flash column chromatography with mixtures of $n$-hexane/ethyl acetate $85 / 15$ to yield the fraction DCM1E1 (586.0 mg). This fraction was further purified by flash column chromatography with mixtures of n-hexane/ethyl acetate $85 / 15,8 / 2$, and ethyl acetate to yield 4 fractions. One of them, DCM1E1B $(385.0 \mathrm{mg})$, was purified twice by thin layer chromatography using mixtures of n-hexane/ethyl acetate $8 / 2$ and $85 / 15$ to yield fraction DCM1E1Bp1p, compound 1 $(15.1 \mathrm{mg})$. Another, DCM1E1C (30.0 mg) was purified by thin layer chromatography using a mixture of $n$-hexane/ethyl acetate $8 / 2$ to yield DCM1E1Cp1, compound 2 (23.1 mg). Another, DCM1E1D (64.0 mg) gave a mixture of compounds 2 and 3 . The fraction DCM1F $(574.0 \mathrm{mg}$ ) was purified by flash column chromatography with a mixture of $n$-hexane/ethyl acetate $85 / 15$ to yield fraction DCM1F2 $(393.0 \mathrm{mg})$ that, after purification by thin layer chromatography using a mixture of $n$-hexane/ethyl acetate $8 / 2$, yielded fraction DCM1F2p, compound $3(57.0 \mathrm{mg})$.

The fraction DCM2 (2.91 g) was purified by flash column chromatography with mixtures of $n$-hexane/ethyl acetate $8 / 2$ and $7 / 3$ to yield three fractions; one of them, DCM2B $(1.00 \mathrm{~g})$, was further purified by flash column chromatography using mixtures of $n$-hexane/ethyl acetate $8 / 2$ and $7 / 3$, and ethyl acetate to yield six fractions; one of them, DCM2B5 yielded compound 4 (168.8 mg). 
Final purification of the compounds for biological testing was achieved by flash chromatography for 4 (white solid, $111.1 \mathrm{mg}$, $n$-hexane/ethyl acetate $8 / 2$ ) or thin layer chromatography for $\mathbf{1}$ (white solid, $<1 \mathrm{mg}, n$-hexane/ethyl acetate 8/2), 2 (white solid, $3.5 \mathrm{mg}, n$-hexane/ethyl acetate $8 / 2$ ), 3 (white solid, $27.8 \mathrm{mg}$, $n$-hexane/ethyl acetate $7 / 3$ ), and for the mixture of 2 and 3 (white solids, 12.1 and $11.2 \mathrm{mg}$, respectively, $n$-hexane/ethyl acetate $8 / 2$ ). On performing spectroscopic analysis isomerization of $\mathbf{2}$ and $\mathbf{3}$ was observed for some of the samples.

\subsubsection{Vomifoliol 5 Extraction}

Acidic extraction of the plant was performed for the isolation of alkaloids. However, a co-extraction compound, vomifoliol (blumenol A) 5, was isolated instead. An amount of $500 \mathrm{~g}$ of $A$. melanoxylon $\mathrm{R}$. Br. was extracted with $1.55 \mathrm{l}$ of $\mathrm{HCl} 0.5 \mathrm{M}$, at room temperature, for $40 \mathrm{~min}$. After centrifugation the supernatant was concentrated and basified with $\mathrm{NH}_{4} \mathrm{OH} 1 \mathrm{M}$. This solution was applied in an isolute ${ }^{\circledR} \mathrm{HM}-\mathrm{N}$ (Biotage, Uppsala, Sweden) column and after elution with dichloromethane and evaporation, the extract Amx (80.4 mg) was obtained.

This extract was purified by thin layer chromatography using a mixture of dichloromethane/ methanol $/ \mathrm{NH}_{4} \mathrm{OH} 95 / 5 / 1$ to yield 3 fractions. Of these, Amx-2 (11.8 mg) was purified by thin layer chromatography using a mixture of dichloromethane/methanol $/ \mathrm{NH}_{4} \mathrm{OH}$ 95/5/1 to yield fraction Amx-2.2B, compound 5 (5.4 mg).

\subsection{Compound Characterization}

Compound $\mathbf{1}$ (unpurified) — ${ }^{1} \mathrm{H}$ NMR spectrum, see Supplementary Materials, Figure S1. Compound 2 (unpurified) - NMR spectra, see Supplementary Materials Figures S2-S8. Compound 3 (unpurified) -NMR spectra, see Supplementary Materials Figures S9-S14. Mixture 1.0:2.0 of compounds 2 and $3-{ }^{1} \mathrm{H}$ NMR spectrum, see Supplementary Materials Figure S15. Mixture 1.0:1.6 of compounds 2 and 3-GC-FID chromatogram, see Supplementary Materials Figure S16. Mixture 1.0:4.4 of compounds 2 and $3-{ }^{1} \mathrm{H}$ NMR spectrum, see Supplementary Materials Figure S17. Compound 4-NMR spectra and ESI-MS spectra, see Supplementary Materials Figures S18-S25. Compound 5 (unpurified)-NMR spectra and ESI-MS spectra, see Supplementary Materials Figures S26-S32.

\subsection{Cell Culture and Treatments}

HCT116 human colon carcinoma cells, commonly used in drug screens, were grown in McCoy's 5A modified medium supplemented with 10\% heat-inactivated fetal bovine serum (FBS) and 1\% antibiotic/antimycotic solution (Gibco, Life Technologies, Paisley, UK). Cells were cultured at $37{ }^{\circ} \mathrm{C}$ under a humidified atmosphere of $5 \% \mathrm{CO}_{2}$.

For cell viability experiments, HCT116 cells were seeded in 96-well plates, at a concentration of $5 \times 10^{3}$ cells/well and allowed to adhere for $24 \mathrm{~h}$. Then, cells were exposed to the test compound, compound 4, previously prepared in sterile DMSO. In order to plot a dose-response curve, cells were exposed to this compound in a range of concentrations between $0.04 \mu \mathrm{M}$ and $4000 \mu \mathrm{M}$ for $72 \mathrm{~h}$. 5-Fluorouracil (5-FU), a cytotoxic agent used in colon cancer treatment, was used as a positive control and DMSO was used as vehicle control. Data are representative of three independent experiments.

\subsection{Viability Assays}

Cell viability of cells treated with compound 4 was evaluated using the CellTiter 96 AQueous Non-Radioactive Cell Proliferation Assay (Promega, Madison, WI, USA) according to the manufacturer's instructions. This colorimetric assay is based in the capacity of metabolic active cells to convert 3-(4,5-dimethylthiazo-2-yl)-5-(3-carboxymethoxyphenyl)2-(4-sulfophenyl)-2H-tetrazolium inner salt (MTS) to formazan, a dye that is soluble in cell culture media. Formazan is quantified by measuring the absorbance at $490 \mathrm{~nm}$ and correlates with the amount of living cells in culture. Absorbance was measured using the GloMax-Multi+ microplate multimode reader (Promega, Madison, WI, USA) and the 
best-fit IC50 value, from at least three independent experiments, was calculated using the $\log$ (inhibitor) versus response (variable slope) function from GraphPad Prism software (version 8.0.2; San Diego, CA, USA).

\section{Conclusions}

In this study, five already known compounds were isolated and as a result some corrections are made to their previous ${ }^{13} \mathrm{C}$ NMR assignments. Cytotoxicity against HCT116 cells was evaluated for two of them, although no positive results were obtained.

As for the utility of the study of the chemistry of invasive species, here illustrated by two extracts of A. melanoxylon, we can propose that they can be used as a source of bioactive metabolites. Based on the literature and our own experimental results, lupeol derivatives 2 and $\mathbf{3}$ show no anticancer activity. Previous reports on vomifoliol (blumenol A) 5 for diverse bioactivities also showed no results. Nonetheless, kolavic acid 15 -methyl ester 4, the most abundant metabolite, is not cytotoxic and has previously been recognized as a bioactive naturally occurring trypanocide that may contribute to anti-inflammatory effects. A. melanoxylon can thus be considered a source for this metabolite.

We further add that it would be interesting to perform a detailed phytochemical study of bark samples of this species in general-ring-barking is presently one of the control measures for this species. Although Freire et al. [29,30] showed the presence of $\Delta^{7}$ phytosterols and phytosteryl glucosides in the dichloromethane extracts of the bark by GC-EIMS, some of them with interesting reported bioactivities, many compounds may have escaped this screening; furthermore, although the antimicrobial bioactivity of the more polar ethanolic and aqueous extracts of the bark of this species is not noteworthy [49], again a detailed phytochemical approach could provide pure metabolites for which many more activities could be considered.

To conclude, although more studies are needed, this paper demonstrates that studying the chemistry of invasive species might provide a utility for this natural and abundant good that is currently underexplored.

Supplementary Materials: The following are available online at https://www.mdpi.com/article/10 $.3390 /$ plants10122698/s1. Figure S1 - ${ }^{1} \mathrm{H}$ NMR spectrum of Lupeol 1 (unpurified) $\left(\mathrm{CDCl}_{3}, 400 \mathrm{MHz}\right.$ ); Figure S2- ${ }^{1} \mathrm{H}$ NMR spectrum of $3 \beta$-Z-coumaroyl lupeol 2 (unpurified) $\left(\mathrm{CDCl}_{3}, 400 \mathrm{MHz}\right)$; Figure $\mathrm{S}^{-}{ }^{13}{ }^{13} \mathrm{C}$ NMR spectrum of 3 $\beta$-Z-coumaroyl lupeol 2 (unpurified) $\left(\mathrm{CDCl}_{3}, 100 \mathrm{MHz}\right)$; Figure $54-D E P T 135$ spectrum of $3 \beta$-Z-coumaroyl lupeol 2 (unpurified) $\left(\mathrm{CDCl}_{3}\right)$; Figure S5-HSQC spectrum of $3 \beta$-Z-coumaroyl lupeol 2 (unpurified) $\left(\mathrm{CDCl}_{3}\right)$; Figure $\mathrm{S} 6-\mathrm{HMBC}$ spectrum of $3 \beta$-Z-coumaroyl lupeol 2 (unpurified) $\left(\mathrm{CDCl}_{3}\right)$; Figure $\mathrm{S} 7$ - COSY spectrum of 3 $\beta$-Z-coumaroyl lupeol 2 (unpurified) $\left(\mathrm{CDCl}_{3}\right)$; Figure S8-NOESY spectrum of $3 \beta$-Z-coumaroyl lupeol 2 (unpurified) $\left(\mathrm{CDCl}_{3}\right)$; Figure $\mathrm{S} 9-{ }^{1} \mathrm{H}$ NMR spectrum of $3 \beta-E-$ coumaroyl lupeol (dioslupecin A) 3 (unpurified) $\left(\mathrm{CDCl}_{3}, 400 \mathrm{MHz}\right.$ ); Figure $\mathrm{S} 10-{ }^{13} \mathrm{C} \mathrm{NMR}$ spectrum of $3 \beta$-E-coumaroyl lupeol (dioslupecin A) 3 (unpurified) $\left(\mathrm{CDCl}_{3}, 100 \mathrm{MHz}\right)$; Figure S11-DEPT135 spectrum of $3 \beta$-E-coumaroyl lupeol (dioslupecin A) 3 (unpurified) $\left(\mathrm{CDCl}_{3}\right)$; Figure $\mathrm{S} 12-\mathrm{HSQC}$ spectrum of $3 \beta$-E-coumaroyl lupeol (dioslupecin A) 3 (unpurified) $\left(\mathrm{CDCl}_{3}\right)$; Figure $\mathrm{S} 13-\mathrm{HMBC}$ spectrum of $3 \beta$-E-coumaroyl lupeol (dioslupecin A) 3 (unpurified) $\left(\mathrm{CDCl}_{3}\right)$; Figure S14-NOESY spectrum of $3 \beta$-E-coumaroyl lupeol (dioslupecin A) 3 (unpurified) $\left(\mathrm{CDCl}_{3}\right)$; Figure $\mathrm{S} 15-{ }^{1} \mathrm{H}$ NMR spectrum of the mixture of $3 \beta$-Z-coumaroyl lupeol 2 and $3 \beta-E$-coumaroyl lupeol 3 (1.0:2.0) $\left(\mathrm{CDCl}_{3}, 500 \mathrm{MHz}\right)$; Figure S16-GC-FID chromatogram of the mixture of $3 \beta$-Z-coumaroyl lupeol 2 and $3 \beta$-E-coumaroyl lupeol 3 (1.0:1.6); Figure S17- ${ }^{1} \mathrm{H}$ NMR spectrum of the mixture of $3 \beta-Z$-coumaroyl lupeol 2 and $3 \beta$-E-coumaroyl lupeol 3 (1.0:4.4) $\left(\mathrm{CDCl}_{3}, 500 \mathrm{MHz}\right)$; Figure S18- ${ }^{1} \mathrm{H}$ NMR spectrum of kolavic acid 15-methyl ester $4\left(\mathrm{CDCl}_{3}, 500 \mathrm{MHz}\right)$; Figure S19- ${ }^{13} \mathrm{C}$ NMR spectrum of kolavic acid 15-methyl ester $4\left(\mathrm{CDCl}_{3}, 125 \mathrm{MHz}\right)$; Figure S20-DEPT135 spectrum of kolavic acid 15-methyl ester $4\left(\mathrm{CDCl}_{3}\right)$; Figure S21-HSQC spectrum of kolavic acid 15-methyl ester $4\left(\mathrm{CDCl}_{3}\right)$; Figure S22- $\mathrm{HMBC}$ spectrum of kolavic acid 15-methyl ester $4\left(\mathrm{CDCl}_{3}\right)$; Figure S23-COSY spectrum of kolavic acid 15-methyl ester $4\left(\mathrm{CDCl}_{3}\right)$; Figure S24-NOESY spectrum of kolavic acid 15-methyl ester $4\left(\mathrm{CDCl}_{3}\right)$; Figure S25-ESIMS spectra of kolavic acid 15-methyl ester 4; Figure S26-1 ${ }^{1} \mathrm{H}$ NMR spectrum of vomifoliol (blumenol A) 5 (unpurified) $\left(\mathrm{CDCl}_{3}, 500 \mathrm{MHz}\right.$ ); Figure S27- ${ }^{13} \mathrm{C}$ NMR spectrum of vomifoliol (blumenol A) 5 (unpurified) ( $\mathrm{CDCl}_{3}, 125 \mathrm{MHz}$ ); Figure S28-DEPT135 spectrum of vomifoliol (blumenol A) 5 (unpurified) $\left(\mathrm{CDCl}_{3}\right)$; Figure S29-HSQC spectrum of vomifoliol (blumenol A) 5 (unpurified) $\left(\mathrm{CDCl}_{3}\right)$; 
Figure S30-HMBC spectrum of vomifoliol (blumenol A) 5 (unpurified) $\left(\mathrm{CDCl}_{3}\right)$; Figure S31-COSY spectrum of vomifoliol (blumenol A) 5 (unpurified) $\left(\mathrm{CDCl}_{3}\right)$; Figure S32-ESI-MS spectra of vomifoliol (blumenol A) 5 (unpurified).

Author Contributions: Conceptualization, P.M.; methodology, P.M., A.L., P.A. and C.M.P.R.; investigation, D.A., S.D. and J.G.; resources A.L., P.A. and C.M.P.R.; writing-original draft preparation, P.M.; writing-review and editing, P.M., A.L., P.A., J.G. and C.M.P.R.; supervision, P.M., A.L., P.A. and C.M.P.R.; funding acquisition, A.L., P.A. and C.M.P.R. All authors have read and agreed to the published version of the manuscript.

Funding: This work has received funding from FEDER through COMPETE 2020 under the Programme grant LISBOA-01-0145-FEDER-016405, and from National Funds through FCT under the Programme grant SAICTPAC/0019/2015 and PTDC/MED-FAR/29097/2017.

Institutional Review Board Statement: Not applicable.

Informed Consent Statement: Not applicable.

Data Availability Statement: Not applicable.

Acknowledgments: This work was supported by the Associate Laboratory for Green Chemistry-LAQV which is financed by national funds from FCT/MCTES (UIDB/50006/2020 and UIDP/50006/2020). GC-FID data obtained by the Analysis Laboratory, LAQV REQUIMTE-Chemistry department, FCT NOVA-PORTUGAL. FCT/MCTES is also acknowledged for supporting the National Portuguese NMR Network (ROTEIRO/0031/2013-PINFRA/22161/2016, co-financed by FEDER through COMPETE 2020, POCI, PORL, and FCT through PIDDAC).

Conflicts of Interest: The authors declare no conflict of interest.

\section{References}

1. Sharma, G.P.; Singh, J.S.; Raghubanshi, A.S. Plant invasions: Emerging trends and future implications. Curr. Sci. 2005, 88, 726-734.

2. Kumar Rai, P.; Singh, J.S. Invasive alien plant species: Their impact on environment, ecosystem services and human health. Ecol. Indic. 2020, 111, 106020. [CrossRef]

3. Almeida, J.D.D.; Freitas, H. The exotic and invasive flora of portugal. Bot. Complut. 2001, 25, 317-327.

4. Almeida, J.D.D.; Freitas, H. Exotic naturalized flora of continental portugal-A reassessment. Bot. Complut. 2006, 30, 117-130.

5. Almeida, J.D.D.; Freitas, H. Exotic flora of continental portugal-A new assessment. Bocconea 2012, 24, $231-237$.

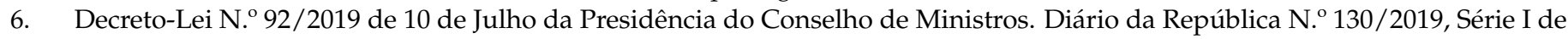
2019-07-10. Decreto-Lei N. ${ }^{\circ}$ 92/2019 | DRE. Available online: https:/ / files.dre.pt/1s/2019/10/19500/0000200010.pdf (accessed on 1 December 2021).

7. Tringali, C.; Oriente, G.; Piattelli, M.; Nicolosi, G. 2 minor dolabellane diterpenoid constituents from a dictyota species. J. Nat. Prod. 1985, 48, 484-485. [CrossRef]

8. Regulation (EU) No 1143/2014 of the European Parliament and of the Council of 22 October 2014 on the Prevention and Management of the Introduction and Spread of Invasive Alien Species. EUR-Lex—32014R1143—EN—EUR-Lex. Available online: https:/ / eur-lex.europa.eu/legal-content/EN/ALL/?uri=CELEX:32014R1143 (accessed on 1 December 2021).

9. Brink, P.T. The Economic Costs of Invasive Alien Species (Ias). Available online: https://www.iucn.org/sites/dev/files/ import/downloads/ten_brink_economic_impacts_of_ias_ptb_of_ieep_at_the_iucn_ep_event_21_feb_2013_final.pdf (accessed on 1 December 2021).

10. Weidlich, E.W.A.; Flórido, F.G.; Sorrini, T.B.; Brancalion, P.H.S.; Peralta, G. Controlling invasive plant species in ecological restoration: A global review. J. Appl. Ecol. 2020, 57, 1806-1817. [CrossRef]

11. Maximo, P.; Ferreira, L.M.; Branco, P.; Lourenço, A. Invasive plants: Turning enemies into value. Molecules 2020, 25, 3529. [CrossRef]

12. Fan, P.; Marston, A. How can phytochemists benefit from invasive plants? Nat. Prod. Commun. 2009, 4, 1407-1416. [CrossRef] [PubMed]

13. Souza-Alonso, P.; Rodríguez, J.; González, L.; Lorenzo, P. Here to stay. Recent advances and perspectives about Acacia invasion in mediterranean areas. Ann. For. Sci. 2017, 74, 55. [CrossRef]

14. Kull, C.A.; Shackleton, C.M.; Cunningham, P.J.; Ducatillon, C.; Dufour-Dror, J.-M.; Esler, K.J.; Friday, J.B.; Gouveia, A.C.; Griffin, A.R.; Marchante, E.; et al. Adoption, use and perception of australian Acacias around the world. Divers. Distrib. 2011, 17, 822-836. [CrossRef]

15. Vieites-Blanco, C.; González-Prieto, S.J. Invasiveness, ecological impacts and control of Acacias in southwestern europe-A review. Web Ecol. 2020, 20, 33-51. [CrossRef] 
16. Le Maitre, D.C.; Gaertner, M.; Marchante, E.; Ens, E.-J.; Holmes, P.M.; Pauchard, A.; O'farrell, P.J.; Rogers, A.M.; Blanchard, R.; Blignaut, J.; et al. Impacts of invasive australian Acacias: Implications for management and restoration. Divers. Distrib. 2011, 17, 1015-1029. [CrossRef]

17. Wilson, J.R.U.; Gairifo, C.; Gibson, M.R.; Arianoutsou, M.; Bakar, B.B.; Baret, S.; Celesti-Grapow, L.; Ditomaso, J.M.; Dufour-Dror, J.-M.; Kueffer, C.; et al. Risk assessment, eradication, and biological control: Global efforts to limit australian Acacia invasions. Divers. Distrib. 2011, 17, 1030-1046. [CrossRef]

18. Lopez-Nunez, F.A.; Marchante, E.; Heleno, R.; Duarte, L.N.; Palhas, J.; Impson, F.; Freitas, H.; Marchante, H. Establishment, spread and early impacts of the first biocontrol agent against an invasive plant in continental europe. J. Environ. Manag. 2021, 290, 112545. [CrossRef]

19. Portugal, P.I.E. Acacia melanoxylon. Available online: https://invasoras.pt/en/invasive-plant/acacia-melanoxylon (accessed on 1 December 2021).

20. Falco, M.R.; Devries, J.X. Isolation of hyperoside ( quercetin-3-d-galactoside ) from flowers of Acacia melanoxylon. Naturwissenschaften 1964, 51, 462-463. [CrossRef]

21. Foo, L.Y. Configuration and conformation of dihydroflavonols from Acacia melanoxylon. Phytochemistry 1987, $26,813-817$. [CrossRef]

22. Hausen, B.M.; Bruhn, G.; Tilsley, D.A. Contact allergy to australian blackwood (Acacia melanoxylon R.Br.): Isolation and identification of new hydroxyflavan sensitizers. Contact Dermat. 1990, 23, 33-39. [CrossRef] [PubMed]

23. Foo, L.Y.; Wong, H. Diastereoisomeric leucoanthocyanidins from the heartwood of Acacia melanoxylon. Phytochemistry 1986, 25, 1961-1965. [CrossRef]

24. King, F.E.; Bottomley, W. The chemistry of extractives from hardwoods.17. The occurrence of a flavan-3-4-diol (melacacidin) in Acacia melanoxylon. J. Chem. Soc. 1954, 1399-1403. [CrossRef]

25. Tindale, M.D.; Roux, D.G. A phytochemical survey of the australian species of Acacia melanoxylon. Phytochemistry 1969, 8 , 1713-1727. [CrossRef]

26. Foo, L.Y. A novel pyrogallol a-ring proanthocyanidin dimer from Acacia melanoxylon. J. Chem. Soc.-Chem. Commun. 1986, 3, 236-237. [CrossRef]

27. Foo, L.Y. Isolation of 4-o-4 -linked biflavanoids from Acacia melanoxylon-1st examples of a new class of single ether-linked proanthocyanidin dimers. J. Chem. Soc.-Chem. Commun. 1989, 20, 1505-1506. [CrossRef]

28. Schmalle, H.W.; Hausen, B.M. Acamelin, a new sensitizing furano-quinone from Acacia melanoxylon R.Br. Tetrahedron Lett. 1980, 21, 149-152. [CrossRef]

29. Freire, C.S.R.; Coelho, D.S.C.; Santos, N.M.; Silvestre, A.J.D.; Neto, C.P. Identification of delta(7) phytosterols and phytosteryl glucosides in the wood and bark of several Acacia species. Lipids 2005, 40, 317-322. [CrossRef] [PubMed]

30. Freire, C.S.R.; Silvestre, A.J.D.; Neto, C.P. Demonstration of long-chainn-alkyl caffeates and 87 -steryl glucosides in the bark of Acacia species by gas chromatography-mass spectrometry. Phytochem. Anal. 2007, 18, 151-156. [CrossRef]

31. Silva, E.; Fernandes, S.; Bacelar, E.; Sampaio, A. Antimicrobial activity of aqueous, ethanolic and methanolic leaf extracts from Acacia spp. And eucalyptus nicholii. Afr. J. Tradit. Complementary Altern. Med. 2016, 13, 130-134. [CrossRef] [PubMed]

32. Correia, R.; Quintela, J.C.; Duarte, M.P.; Gonçalves, M. Insights for the valorization of biomass from portuguese invasive Acacia spp. In a biorefinery perspective. Forests 2020, 11, 1342. [CrossRef]

33. Pereira Beserra, F.; Xue, M.; Maia, G.; Leite Rozza, A.; Helena Pellizzon, C.; Jackson, C. Lupeol, a pentacyclic triterpene, promotes migration, wound closure, and contractile effect in vitro: Possible involvement of pi3k/akt and p38/erk/mapk pathways. Molecules 2018, 23, 2819. [CrossRef]

34. Chang, C.-I.; Kuo, Y.-H. Threee new lupane-type triterpenes from Diospyros maritima. Chem. Pharm. Bull. 1998, 46, 1627-1629. [CrossRef]

35. Karalai, C.; Laphookhieo, S. Triterpenoid esters from bruguiera cylindrica. Aust. J. Chem. 2005, 58, 556-559. [CrossRef]

36. Ali, M.; Heaton, A.; Leach, D. Triterpene esters from australian. Acacia J. Nat. Prod. 1997, 60, 1150-1151. [CrossRef]

37. Kuo, Y.H.; Chang, C.I.; Li, S.Y.; Chou, C.J.; Chen, C.F.; Kuo, Y.H.; Lee, K.H. Cytotoxic constituents from the stems of diospyros maritima. Planta Med. 1997, 63, 363-365. [CrossRef]

38. Nyasse, B.; Ngantchou, I.; Tchana, E.M.; Sonke, B.; Denier, C.; Fontaine, C. Inhibition of both trypanosoma brucei bloodstream form and related glycolytic enzymes by a new kolavic acid derivative isolated from entada abyssinica. Pharmazie 2004, 59, 873-875. [CrossRef] [PubMed]

39. Tchinda, A.T.; Fuendjiepa, V.; Mekonnenb, Y.; Ngoa, B.B.; Dagne, E. A bioactive diterpene from entada abyssinica. Nat. Prod. Comm. 2007, 2, 9-12. [CrossRef]

40. Vargas, F.D.S.; Almeida, P.D.O.D.; Aranha, E.S.P.; Boleti, A.P.D.A.; Newton, P.; Vasconcellos, M.C.D.; Junior, V.F.V.; Lima, E.S. Biological activities and cytotoxicity of diterpenes from copaifera spp. Oleoresins. Molecules 2015, 20, 6194-6210. [CrossRef]

41. González, A.G.; Guillermo, J.A.; Ravelo, A.G.; Jimenez, I.A.; Gupta, M.P. 4,5-dihydroblumenol a, a new nor-isoprenoid from perrottetia multiflora. J. Nat. Prod. 1994, 57, 400-402. [CrossRef]

42. Xiao, W.-L.; Chen, W.-H.; Zhang, J.-Y.; Song, X.-P.; Chen, G.-Y.; Han, C.-R. Ionone-type sesquiterpenoids from the stems of ficus pumila. Chem. Nat. Compd. 2016, 52, 531-533. [CrossRef]

43. Liu, X.; Tian, F.; Zhang, H.-B.; Pilarinou, E.; Mclaughlin, J.L. Biologically active blumenol a from the leaves ofannona glabra. Nat. Prod. Lett. 1999, 14, 77-81. [CrossRef] 
44. Dat, N.T.; Jin, X.; Hong, Y.-S.; Lee, J.J. An isoaurone and other constituents from trichosanthes kirilowii seeds inhibit hypoxiainducible factor-1 and nuclear factor-kb. J. Nat. Prod. 2010, 73, 1167-1169. [CrossRef] [PubMed]

45. Rahim, A.; Saito, Y.; Fukuyoshi, S.; Miyake, K.; Goto, M.; Chen, C.H.; Alam, G.; Lee, K.H.; Nakagawa-Goto, K. Paliasanines a-e, 3,4-methylenedioxyquinoline alkaloids fused with a phenyl-14-oxabicyclo[3.2.1]octane unit from melochia umbellata var. Deglabrata. J. Nat. Prod. 2020, 83, 2931-2939. [CrossRef]

46. Yang, J.M.; Liu, Y.Y.; Yang, W.C.; Ma, X.X.; Nie, Y.Y.; Glukhov, E.; Gerwick, L.; Gerwick, W.H.; Lei, X.L.; Zhang, Y. An antiinflammatory isoflavone from soybean inoculated with a marine fungus aspergillus terreus c23-3. Biosci. Biotechnol. Biochem. 2020, 84, 1546-1553. [CrossRef] [PubMed]

47. Mclean, S.; Reynold, W.F.; Yang, J.-P.; Jacobs, H.; Jean-Pierre, L.L. Total assignment of the $1 \mathrm{~h}$ and ${ }^{13} \mathrm{C}$ chemical shifts for a mixture of cis- and trans-p-hydroxycinnamoyl esters of taraxerol with the aid of high-resolution, ${ }^{13} \mathrm{C}$-detected, ${ }^{13} \mathrm{C}$ - $1 \mathrm{~h}$ shift correlation spectra. Magn. Reson. Chem. 1994, 32, 422-428. [CrossRef]

48. Stahl, E. Thin-Layer Chromatography a Laboratory Handbook, 2nd ed.; Springer: Berlin/Heidelberg, Germany, 1969.

49. Neiva, D.M.; Luís, Â.; Gominho, J.; Domingues, F.; Duarte, A.P.; Pereira, H. Bark residues valorization potential regarding antioxidant and antimicrobial extracts. Wood Sci. Technol. 2020, 54, 559-585. [CrossRef] 